\title{
Engelli Bireylerin Gözüyle Özel Eğitim ve Rehabilitasyon Merkezlerindeki Eğitim Durumlarının İncelenmesi
}

\author{
Abdurrahman MENG $\dot{\mathrm{I}}^{1}$
}

\section{Öz}

Bu araştırma, engelli bireylerin gözüyle Özel Eğitim ve Rehabilitasyon Merkezlerindeki eğitim durumlarının nasıl olduğunu ortaya çıkartma amacını gütmektedir. Araştırmada nitel araştırma yönteminden hareketle nitel araştırmalarında kullanılan durum çalışması deseni model olarak seçilmiştir. Araştırma, Van il merkezinde bulunan Özel Eğitim ve Rehabilitasyon Merkezlerinde gerçekleşmiştir. Araştırma engelli 18 katılımcıyla 2018-2019 döneminde dört aylık bir çalışma sonunda yapılmıştır. Araştırma verileri yarı-yapılandırılmış görüşme formları yoluyla toplanılmış ve betimsel analize tabi tutulmuştur. Araştırma verileri dört kategoriye bağlı olarak birden fazla alt kategori şeklinde sunulmuştur. Araştırmada katıllımcıların Özel Eğitim ve Rehabilitasyon Merkezlerine haftada iki gün ve iki saat gidebildikleri, genel olarak eğitimlerinden memnun kaldıkları, Özel Eğitim ve Rehabilitasyon Merkezleri sayesinde engel durumlarını kabul ettikleri, sosyal çevrelerinin genişlediği, yalnızlık duygusundan kurtuldukları ve dolayısıyla bu kurumlar sayesinde yaşam bağlarının güçlendiği ve mutlu olduklarına dair sonuçlara ulaşılmıştır. Keza bu araştırma, engelli bireylerin Özel Eğitim ve Rehabilitasyon Merkezlerindeki eğitim durumlarına işaret ettiği için önemli bir araştırma olmuştur. Araştırma sonunda ulaşılan bulgulardan hareketle bundan sonra yapilacak araştırmalara yönelik önerilerde bulunmuştur.

Anabtar Kelimeler: Engellilik, Engelli Birey, Özel Eğitim ve Rehabilitasyon Merkezi

\section{Examination of Special Education and Rehabilitation Centers from the Aspect of Education through the Eyes of Disabled People}

\section{Abstract}

The aim of this research is to reveal the educational status of Special Education and Rehabilitation Centers through the eyes of disabled people. Among the qualitative research methods, the case study pattern was chosen as a model. The research was carried out at the Special Education and Rehabilitation Centers in the center of Van. The study was conducted during of a four-month study with 18 disabled participants in 2018-2019 period. Research data were collected through semi-structured interview forms and subjected to descriptive analysis. Research data is presented in more than one subcategory depending on four categories. In the study, it was concluded that the participants were able to go to the Special Education and Rehabilitation Centers two days a week for two hours and that they were satisfied with their education in general, and accepted their status of disability through the Special Education and Rehabilitation Centers, their social circles expanded, they got rid of the sense of loneliness and therefore their living ties were strengthened and they are happy thanks to these institutions. Likewise, this research has been an important research since it indicates the educational status of disabled individuals in Special Education and Rehabilitation Centers. Based on the findings of the research, suggestions were made for the future researches.

Key Words: Disability, Disabled Individuals, Special Education and Rehabilitation Center

\section{Atıf İçin / Please Cite As:}

Mengi, A. (2020). Engelli bireylerin gözüyle özel eğitim ve rehabilitasyon merkezlerindeki eğitim durumlarının incelenmesi. Manas Sosyal Arasttrmalar Dergisi, 9(1), 19-33.

Geliş Tarihi / Received Date: 15.03.2019

Kabul Tarihi / Accepted Date: 24.06.2019

\footnotetext{
${ }^{1}$ Dr. Öğr. Üyesi - Van Yüzüncü Yll Üniversitesi, Eğitim Fakültesi, Özel Eğitim Bölümü, abdurrahmanmengi@yyu.edu.tr ORCID: 0000-0000-5903-254X
} 


\section{Giriş}

İnsan doğumundan itibaren varlığını bir toplum içinde bulur. Keza insan yaşamının ilk yıllarından itibaren sosyal evrende var olmaya ve bir kimlik kazanmaya çalışır. İnsan kimlik kazanırken içinde yaşadığı toplumsal yap1 veya sosyal evreninden etkilenerek bireysel kimliğini inşa eder. İnsanın içinde yaşadığı sosyolojik evreni ne tür özelliklere sahipse kendisinin bireysel kimliği de o yönde gelişir. Dolayısıyla insan, yaşadığ1 toplumdan ayr1 düşünülemez. Çünkü insan doğduğu zaman ismini bile bir aile içinde kazanır. Bu yüzden insanın ailesi ve sosyal çevresi kendisine nasıl bir anlam, görev veya sorumluluk yüklerse, birey o yönde kimlik kazanır ve kazandığı kimliğe uygunsa belli haklara sahip olur. Böylece insan toplumun kendisine sundukları imkânların üzerine bir şeyler inşa ederek ve onları takip ederek sosyal bir kimlik kazanır. Her toplum, sağlam ve sağlıklı bir bünyeye sahip ve sosyal uyumu yüksek bireylere sahip olmak ister. Fakat bazen yaşamın sundukları gerçekler ile sosyal gerçekler örtüşmeyebilir. Yani toplumun arzuladığı ideal sosyal olgu ile gerçek sosyal olgu arasında paradoksal bir durum ortaya çıkabilir. Diğger bir ifadeyle toplum, çoğu zaman kendisi için sağlam ve sağlıklı bir bünyeye sahip ve sosyal uyumu yüksek bireyler isterken zaman zaman hiç arzulamadığı sorunlara sahip bireylerin varllğıyla da karşılaşmak zorunda kalır. Bu istenmeyen durum ise toplumu engelli bireylere karşı olumsuz tutuma sevk eder. Böylece engelli bireyler toplumda ötekileşme, damgalanma riskiyle karşı karşıya kalır.

Engelli kavramı, yetersizliği olan bireyin çevreyle etkileşiminde karşılaştı̆̆ problemi tanımlamaktadır (Ataman, 2009; Usta, 2009). Başka bir deyişle engelli terimi ilk zamanlar tıbbi model bağlamında, bireyin biyolojik/fizyolojik ve psikolojik kayıp ve anatomik yapının fonksiyonlanndaki normal dışı durum veya gelişimi olarak tanımlanmıştır (Oymak, 1997 Akt: Güleryüz, 2009). Bu tanım sonradan sosyal model bağlamında yeni bir anlam kazanmıştır. Yeni tanımda yani sosyal model bağlamında engellilik, bireyin fiziksel olarak yetersizliğini değil, daha çok toplumsal alanların farklı gelişen bireyler açısında yetersizliğine dikkat çeker. Yani engellilik, bireylerin parçası olduğu toplumun kendisine sağladığ1 fiziksel alt yap1, toplumun farklı gelişenlere yönelik kabul düzeyi ve kültürel gelişmişlikle ilişkili olduğu savı ön plana çıkmıştır (Burcu, 2013, s. 39). Engellilik; "bireyin yașadı̆g sürece yaș, cinsiyet, sosyal ve külltürel faktörlere bağh olarak toplumda oynamasi gereken rolleri yetersizlik yüzünden yerine getirememesi durumudur" (Ulutaşdemir, 2007, s. 120). Yani engel, kişinin bir şeyi yapmak isteyip de kendisini sınırlandıran bir sorun ve yetersizlikten dolayı yapamaması veya engellenmesidir. Örneğin, bireyler, bedensel, zihinsel, sözel, işitsel, duygusal gibi sınırlılıklar nedeniyle kendi kendine yeterli olamamakta ve çoğu zaman başkalarına bağımlı olarak yaşama zorunda kalmaktadırlar. Engelli kavramı ise; "beden, zekâ, duygu, eğitim ya da toplumsal kossullar nedeniyle yetersiz. durumda bulunan kişilere" (Okan ve Okan, 2006, s. 14) veya "firitiksel, rubsal ya da zibinsel olarak herhangi bir

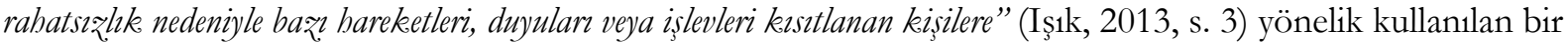
sifatlandirmadir.

Engelliliğin oluşum nedenleri üç başlık altında toplanabilir. Bunlar; "a) doğum öncesi oluşan nedenler: annenin yaşı, beslenmesi, kullandiğ ilaçlar, radyasyona maruz kalması gibi nedenlerdir. b) doğum sirası olusan nedenler: erken-geç doğum, kordon dolanması, doğum sirası kazalardır. c) doğum sonrası olusan nedenler: enfeksiyona maruz kalma, çocuğun gę̧irdiği hastallklar, hastallklarda yanlış ve geç müdahale gibi nedenlerdir” (Kulaksızoğlu, 2003, s. 63). Dünya nüfusunun önemli bir kısmını oluşturan engelli bireylerin Türkiye nüfusu içindeki payı da yüksektir. Dünya Sağllk Örgütü'nün (World Health Organization [WHO], 2011) verilerine göre dünya nüfusunun yaklaşık \%15’i engellidir. Türkiye Özürlüler Araştırması'nın [TÖA] 2002 verilerine göre ise Türkiye nüfusunun \%12.29’u engellidir (Türkiye İstatistik Kurumu [TÜIK], 2002). Türkiye'de engelli nüfusun eğitim düzeyleri ve istihdam edilme oranları düşüktür.

Eğitim, bireylerin sosyal, duygusal, psikomotor ve bilişsel gelişimini sağlayan ve yaşamın her basamağında gerçekleşen bir olgudur. Bireyler aldıkları eğitim sayesinde sosyalleşmelerini gerçekleştirirler. Bireyler sosyalleşme süreçlerini ilkin aile ortamında yaşarlar. Daha sonra okul sayesinde planl, programl, kapsamlı ve nitelikli bir sosyalleştirme programına tabi olurlar. Bireyler zaman zaman arkadaşlık ve akran gruplarında da sosyalleşme firsatını yakalamaktadırlar. Dolayısıyla bireyler yaşamının ilk yıllarından son yıllarına kadar sürekli bir eğitim veya sosyalleşme süreci içinde olmaktadırlar. Bireylerin içinde yaşadıkları topluma uyum sağlayabilmeleri veya sosyalleşmeleri için çeşitli eğitimler verilmektedir (Giddens, 2006). "Ë̈itim; genel anlamda bireyde davranıs değistirme sürecidir. Genis anlamda ise eğitim; bireyin toplum standartlarm, inançlarnı ve yaşam yollarmı kaz̧anmasinda etkili olan tüm sosyal süreģlerdir" (Demirel ve Kaya, 2012, s. 5).

Toplumdaki her birey gibi, engelli bireyler için de eğitim, istihdam, toplumsallaşma konularnnda gerekli sosyal, ekonomik ve fiziksel koşulların, tedavi, bakım, rehabilitasyon olanaklarının sağlanması önemlidir (Aykara, 2010). Özellikle Birleşmiş Milletler Engelli Hakları Sözleşmesinin 24. Maddesinin 2. 
Fıkrasında bu anlaşmaya imza atan tüm devletler, tüm engellileri içine alan ve onları toplumdan dışlamadan diğer her birey gibi ömür boyu öğrenim veren bir eğitim sistemi hazırlamak durumundadırlar (Akbulut vd., 2014). Bu sözleşme engelli bireylerin haklarının korunması anlamında uluslararası düzeyde son derece önemli bir anlaşmadır. Çünkü bu anlaşma ile Birleşmiş Milletlere üye tüm devletler, engelli bireylerin özel gereksinimlerini karşılayacak şekilde özel eğitim hizmetlerini sunmak zorundadır. Uluslararası düzeyde olduğu gibi, ulusal düzeyde de engelli bireylerin eğitim haklarını elde etmelerinin engellenemeyeceğini temin etmek bağlamında 2005 yllında çıarılan 5378 sayılı Engelliler Hakkında kanun oldukça önemlidir (Sart, 2007). Bu kanunla engelli bireylerin yetersizliklerinin türü ve derecesine göre veya eğitsel tanısına göre her kademede özel eğitime dâhil edilmesi zorunludur. Keza özel eğitim hizmetinden; zihinsel, bedensel, işitme, konuşma, görme, duygusal, sosyal ve ruhsal sorunu olanlar, otizmli ya da öğrenme güçlüğü olan bireyler veya özel/üstün yeteneği olan bireyler yararlanmaktadır.

Eğitim programları, bireylerin eğitimi için çoğu zaman ortak amaçlar belirlemektedir. Ancak bireyleri birbirinden farklı kılan bazı özellikleri bulunmaktadır. Bireylerin bedensel, zihinsel ve ruhsal olarak farklı gelişmeleri, öğrenme kapasitelerinin farklı olmaları, duygu durumlarının ve algı düzeylerinin farklı olmaları onlar için farklı eğitim programlarının gerekliğini zorunlu kılmaktadır. Bu araştırma da daha çok engelli bireylerin Özel Eğitim ve Rehabilitasyon Merkezlerinde aldıkları özel eğitim hakkındaki görüşlerine odaklanmaktadır.

Engelli bireylerin özel eğitim ihtiyacını karşılamak Milli Eğitim Bakanlı̆̆ı’nın (MEB) sorumluluğundadır. Özel eğitimin en temel amaçlarından biri de engelli bireylerin bağımsız yaşam becerilerini desteklemek ve bireylerin sosyalleşmelerini sağlamaktır (Akçamete, 2010). Bu nedenle özel eğitim hizmetleri engelli bireyler için erken çocukluk döneminden itibaren, alanında uzman eğitimciler, özel hazırlanmış ortamlar, eğitim programları ve eğitim materyalleri yardımıyla gerçekleşmektedir (Akçamete, 2009). Bu kapsamda özel eğitim hizmetleri; "yetersizllikten etkilenmis çocuklara sunulan, üstün özellikleri olanlarn yetenekleri doğrultusunda kapasitelerinin en üst düreye çıkmasm sağlayan, yetersizliğg engele dönïstürmeyi önleyen, engelli bireyi kendine yeterli bale getirerek, topluma kaynaşmasın ve bağımsız, üretici bireyler olmasim destekleyecek becerilerle donatan eğitim olarak tanmlanmaktadır" (Mengi, 2016, s. 216). 573 Sayll Özel Eğitim Hakkında Kanun Hükmünde Kararname'nin (KHK) 3. Maddesi b firkasında ise özel eğitim şöyle tanımlanı;; "Özel eğitim gerektiren bireylerin eğitim ibtiyaçlarm karşlamak için özel olarak yetiștirilmiş personel, geliștirilmiş eğitim programlar ve yöntemleri ile onlarn ö२ür ve özelliklerine uygun ortamlarda sürdürülen eğitimdir" (https://orgm.meb.gov.tr/erş.tar.26.05.2019). Bu tanıma dayanarak özel eğitimin birçok özel amacının olduğunu belirtmek gerekir. Bunlar; engelli bireyin toplumda bir konum veya sayginlı edinmesini sağlamak, engelli bireyin bağımsız yaşam becerilerini destekleyerek bireylerin kendi kişisel ihtiyaçlarını gidermesine yardımcı olmak veya başkalarına muhtaç olmadan bağımsız yaşam becerilerini geliştirmek, engelli bireylerin sosyalleşmesini destekleyip toplumsal uyumunu sağlayarak gibi bir dizi özel amaçlardır. Diğer taraftan özel eğitimin bir de genel amaçları söz konusudur. Bunlar, "toplum içindeki rollerini gerçekleștirebilen, başkalar ile iyi ilişkiler kurabilen, işbirliği içinde çalsşabilen, çevresine uyum sağlayabilen, üretici ve muthu bir vatandas olarak yetişsebilen bireyler yetiştirmek; kendi kendilerine yeterli bir duruma gelmeleri için temel yaşam becerilerini geliştirmelerine yardimc olmak; uygun eğitim programlar ile özel yöntem, personel ve araç gerec kullanarak ilgileri, ibtiyaçlar, yetenekleri ve yeterlilikleri doğrultusunda üst ögrenime, is ve meslek alanlarna ve hayata bažrlanmalarnna yardımc olmak" (Aydın, 2017, s. 15-16) gibi amaçlardır.

Engelli bireylere eğitim hizmetleri sunmak, onları toplumsal yaşama hazırlamak ve bağımsız bir yaşam becerisini kazanmak için özel eğitimde bazı uygulamalar bulunmaktadır. Türkiye'de iki farklı kurum engelli bireylerin eğitimine yönelik özel eğitim hizmetlerini sunmaktadır. Birincisi, Milli Eğitim Bakanlı̆̆’nın bünyesinde özel eğitim hizmetlerini veren resmi eğitim kurumlarıdır. Bu kurumlarda, her hangi bir engel derecesinden hafif olarak etkilenen bireylere yönelik özel eğitim hizmeti verilmektedir. Bu bireylere öz bakım, temel yaşam ve akademik becerilerini geliştirmek, topluma uyumlarını sağlamak için belli kazanım, beceri ve davranış sağaltımına yönelik eğitim programları uygulanmaktadır (MEB, 2005). Dolayısıyla Türkiye'de özel eğitim uygulamaları resmi eğitim kurumları olan genel okullarda veya özel eğitim okullarında yapılmaktadır. Resmi eğitim kurumları olan genel/normal okullarda daha çok kaynaştırma öğrencileri veya hafif düzeyde eğitsel tanıyı alan öğrenciler özel eğitim imkânında yararlanmaktadır. Kaynaştırma öğrencileri genelde akranlarıyla hiçbir ayrımcılığa maruz kalmadan aynı sınıfta eğitim alırken haftanın belli ders saatinde destek eğitim odalarında Bireyselleştirilmiş Eğitim Programı (BEP) ile özel eğitimden faydalanmaktadır. Hafif düzeyde eğitsel tanıyı alan öğrencilerin çoğu genel/normal okulların bünyesinde bulunan ve akranlarıla birlikte eğitim aldıkları genel eğitim sınıflarında eğitim almaktadır. Ayrıca bunların bir kısmı özel eğitim sınıflarında ve destek eğitim odalarında da eğitim almaktadırlar. 
Ayrıca resmi özel eğitim okulları olan Özel Eğitim İlk ve Orta Okulları, Özel Eğitim Mesleki Eğitim Merkezleri, İş Uygulama Okulları, İşitme ve Görme Engelliler Okulları gibi kurumlardan da özel eğitim hizmetleri verilmektedir. İkincisi ise Milli Eğitim Bakanlığ 5580 Sayılı Özel Eğitim Kurumları Kanunu kapsamında açılan Özel Eğitim ve Rehabilitasyon Merkezleridir. Bu kurumlarda ise, genelde her hangi bir engel derecesinden orta ve ağır olarak etkilenen bireylere yönelik özel eğitim hizmeti verilmektedir. Buralarda bireysel ve grup eğitimleri şeklinde iki farklı kategoride özel eğitim faaliyetleri verilmektedir. Bu kurumlarda eğitim gören engelli bireyler haftada iki saat bireysel, bir saat da grup eğitimini alabilmektedir. $\mathrm{Bu}$ kurumlarda, engelli bireylerin etkilendiği yetersizliğin giderilmesi, mevcut olan yeteneklerinin geliştirilmesi için fiziksel, psikolojik, eğitimsel, gelişimsel, sosyal ve mesleki gibi farklı modüller kapsamında özel eğitim programları uygulanmaktadır (MEB, 2007). Dolayısıyla Türkiye'de resmi Özel Eğitim Kurumları dışında Özel Eğitim ve Rehabilitasyon Merkezleri de özel eğitim hizmetlerini yürütmektedir. Bu öğrencilerin tamamının "ücreti devlet tarafindan karşılanmaktadır” (Kulaksızoğlu, Çitil, vd., 2011; Arslan, 2014).

Özel Eğitim Kurumları Kanunu'nda Özel Eğitim ve Rehabilitasyon Merkezleri: “Özel eğitim gerektiren bireylerin konusma ve dil gelisim gügllïgü, ses bozukluklar, zibinsel, fir̨iksel, duyusal, sosyal, duygusal veya davranıs problemlerini ortadan kaldirmak ya da etkilerini en az seviyeye indirmek, yeteneklerini yeniden en üst seviyeye çıarmak, temel öz bakım becerilerini ve bağzmsı yaşam becerilerini geliştirmek ve topluma uyumlarm sağlamak amacryla faaliyet gösteren özel ögretim kurumlarn” şeklinde tanımlanmıştır (www.resmigazete.gov.tr/erş. tar.: 28.02.2019). Türkiye'de ilk zamanlar Özel Eğitim ve Rehabilitasyon Merkezleri Sosyal Hizmetler ve Çocuk Esirgeme Genel Müdürlüğ̈̈’ne bağlı kurumlar iken 2006 yllinda bu kurumlar MEB'e devredilmiştir. Dolayısıyla Türkiye'de MEB'e bağlı Özel Eğitim ve Rehabilitasyon merkezlerinin belli başlı amaçları bulunmaktadır. Bunlar; engelli bireylere bireysel ve grupla eğitim hizmeti vermek, engelli bireyin ailesini çocuğun engel durumu ve eğitimiyle ilgili bilgilendirmek, ailenin kabullenme sürecini hızlandırmak, bireyi topluma kazandırmak ve sosyalleşmesini sağlamak için etkinlikler yapmak gibi belli amaçları bulunmaktadır (www.resmigazete.gov.tr/erş. tar.: 28.02.2019).

Türkiye'de Özel Eğitim ve Rehabilitasyon Merkezlerinde eğitim gören kişi sayısı her geçen yll daha da artmaktadır. 2007 yllında Özel Eğitim ve Rehabilitasyon Merkezlerinde 90.174 kişi özel eğitim ve rehabilitasyon hizmetinden yararlanabilmiştir (Özbey, 2009). 2017 yll verilerine göre ise, Özel Eğitim Kurumları Derneği tarafindan Antalya'da düzenlenen 'Özel Eğitimde Rehabilitasyon Merkezlerinin Rolü ve Eğitim Niteliklerinin Artırılması' sempozyumuna davetli konuşmacı olarak katılan MEB Müsteşarı Yusuf Tekin'in verdiği bilgilere göre, Türkiye'deki Özel Eğitim ve Rehabilitasyon Merkezi sayısı 2 bin 178 'dır. Türkiye'de eğitsel tanılaması yapılmış yaklaşık 800 bin engelli birey bulunurken bu bireylerden yaklaşı 350 bini Özel Eğitim ve Rehabilitasyon Merkezlerinden destek eğitimi almaktadır. Bu kurumlarda görme, işitme, dil-konuşma, spastik, zihinsel, ortopedik ve ruhsal olmak üzere 7 engel türünde bireylere destek eğitim programları uygulanmaktadır. Türkiye'de yeterli sayıda özel eğitim öğretmeni olmadığı için bu merkezlerde çalışacak eğitim personeli MEB tarafında hizmet içi eğitim yoluyla yetiştirilmektedir. Özel Eğitim ve Rehabilitasyon Merkezlerinden çalışacak eğitim personeli sınıf öğretmeni, okul öncesi öğretmeni ve çocuk gelişimi alanlarından mezun olup ataması gerçekleşmeyen öğretmen adayları arasından seçilerek belli kurslara tabi tutulmaktadır. Böylece özel eğitim alanında destek eğitimi verecek uzman öğretici yetiştirme kurslarında 160 saat teorik, 80 saat uygulamalı olmak üzere 240 saatlik hizmet içi eğitim sürecinden geçerek Özel Eğitim ve Rehabilitasyon Merkezlerinde çalışmaya hak kazanmaktadırlar. Ayrıca pedagojik formasyon eğitimlerini tamamlamış olan sosyoloji ve felsefe mezunu olan öğretmen adaylarına da bu kurumlarda çalısma hakkı verilmektedir. Bunlar da yukarıda belirtilen çerçevede eğitimler aldıktan sonra özel eğitim kurumlarının rehberlik servislerinden öğretmenlik yapabilmektedirler. Dolayısıyla şimdiye kadar MEB tarafindan "toplam 12 bin 174 rehber ögretmen, 16 bin 113 qibinsel engelliler sinvf ögrretmeni, 531 issitme engelliler sinn fögretmeni ve 12 bin 632 özel eğitim u₹man ögreticisi olmak üzere toplamda 37 bin 150 kişi Özel Ë̈itim ve Rehabilitasyon Merkezlerinde istibdam edilebilecek sekilde sertifikalandrrlmustur." (MEB, 2017, www.hurriyet.com.tr/erş.tar.:08.03.2019). Ancak engelli bireylerin Özel Eğitim ve Rehabilitasyon Merkezlerinde nasıl bir eğitim aldığı tartışma konusudur. Çünkü bu kurumlar Milli Eğitim Bakanlğg denetiminde olsalar da temelde ücret karşıllğında engelli bireylere özel eğitim hizmetlerini sunmaktadırlar. Dolayısıyla çoğu kez bu kurumlar ticari birer kurum olarak görülmekte ve eğitim kaliteleri sorgulamaktadır. Ayrıca bu kurumların engelli bireylere, haftada iki saat bireysel ve dört saat grup eğitimi vermeleri yani çok az bir ders saati ile eğitim vermeleri hususu engelli bireyler tarafinda sürekli şikâyet ve tartışma konusu yapılmaktadır. Bu nedenle Özel Eğitim ve Rehabilitasyon Merkezlerinin eğitim durumlarının veya kalitesinin nasıl olduğu konusu araştırmaya değer bir konu olarak görülmüştür. Ayrıca bu konuda nitelikli veriye ulaşmak için de bu sorunu bizatihi yaşayan engelli bireylerin görüşlerine ihtiyaç duyulmuştur. 
Şüphesiz ki bu konuyu aydınlığa kavuşturacak en önemli şey ise, bu kurumlara yıllardır giden engelli bireylerin eğitimle ilgili sahip oldukları tecrübeleri ve dolayısıyla tecrübelerini ortaya koyacak görüşleridir. Dolayısıyla, bu araştırma, engelli bireylerin gözüyle Özel Eğitim ve Rehabilitasyon Merkezlerindeki eğitim durumlarının nasıl olduğunu ortaya çıkartma amacını gütmektedir. Bu amaç doğrultusunda aşağıdaki araştırma sorularına cevap aranmışır:

1. Engelli bireylerin Özel Eğitim ve Rehabilitasyon Merkezlerine devam etme sıklıkları nedir?

2. Engelli bireyler, Özel Eğitim ve Rehabilitasyon Merkezlerinde aldıkları eğitimi nasıl değerlendirmekteler?

3. Engelli bireylerin Özel Eğitim ve Rehabilitasyon Merkezleri hakkındaki görüşleri nelerdir?

\section{Yöntem}

Bu bölümde araştırmanın desenine değinilmiş, çalışma grubu hakkında bilgiler verilmiş, veri toplama araçları tanıtılmış ve veri analizi hakkında bilgiler sunulmuştur.

\section{Araştırma Modeli/Deseni}

$\mathrm{Bu}$ araştırmada nitel araştırma yöntemlerinden olan durum çalışması deseni kullanılmıştır. "Nitel araştırma, bir alan veya yaşam ortamı ile temasin yoğun ve/veya uzun bir zaman dilimini kapsayacak bir biçimde sürdürülmesiyle yürütülür. Bu durumlar, genellikle insanlarn, gruplarn, toplumlarn ve örgütlerin gündelike hayatm yansitan 'siradan' veya normal durumlardir' (Punch, 2005, s. 142). Dolayisiyla nitel araştırmalar olay ve olguların sosyal yönü ile ilgilenir. Nitel araştırma, "sosyal olgular, bağh olduklar ve içinde yer aldiklar ortamda doğal görünümleriyle gö̋lem, görïsme ya da belgeleri değerlendirmek yoluyla bilgi edinme ve bu bilgileri analiz ederek. kuram geliştirme" olarak tanımlanabilir (İslamoğlu ve Alnıaçık, 2013, s. 204). Nitel araştırmada En temel nitel veri toplama yöntemleri; görüş̧me (mülakat), gözlem, katılımcı gözlem ve belgeler olarak sıralanabilir (Punch, 2005, s. 165). Ayrıca deneysel gözlemler, fotoğrafik teknikler (video kayıtları), görsel analizler, tarihsel analizler (histografi), sosyometri, sosyodrama, benzer etnometodolojik deneyimler, etnografik araştırma gibi teknikler sayılmaktadır (Berg, 2001, s. 3). Durum çalışması, betimsel araştırma yöntemleri arasında yer alır ve sosyal bilimlerde psikoloji, sosyoloji ve özellikle eğitim bilimleri alanında kullanılmaktadır. Durum çalışmasında "durum, bir bireyden bir këy balkina ya da bir olaydan belirli bir programin uygulanmast gibi bir diæ̧i işleme göre değğsebilir" (Fatma ve Yasemin, 2015, s. 119-120). Durum çalışması özellikle eğitim alanında nitel araştırmalarda yaygın olarak kullanılan bir yöntemdir. Araştırma sürecinde daha çok nasıl soruları araştırmanın yönünü belirler. Durum çalışmasında kuramsal önermelerden hareketle oluşturulan araştırma sorularına uygun veriler toplanır ve betimsel analize tabi tutulur (Fatma ve Yasemin, 2015, s. 119-120). Dolayısıyla bu araştırma da engelli bireylerin eğitim durumlarına odaklandığı için durum çalışması deseninden hareketle betimsel bir araştırmadır.

\section{Araştırmanın Çalışma Grubu}

Araştırma, Van ili merkez ilçelerinde bulunan 18 Özel Eğitim ve Rehabilitasyon Merkezinden 12 tanesinde gerçekleştirilmiştir. Araştırmanın çalışma grubunu ise bu kurumlarda eğitim alan 18 Engelli bireyden oluşmaktadır. Bu bireylerin 8'i görme, 6'sı ortopedik, 2'si Multiple Skleroz (MS) ve diğer 2'si ise Serebral Palsi (SP) tanısına sahiptir. Çalışma grubunun farklı engel türlerinden seçilmesine dikkat edilmiştir. Yani görme, ortopedik, MS ve SP tanısına sahip bireylerin seçilmesinin nedeni; bu bireylerin zihinsel olarak herhangi bir engellerinin bulunmamas1, sorulara cevap verebilecek kapasitede olmaları ve kendilerini ifade edebilmeleridir. Dolayısıyla bu araştırmada amaçlı örneklemden hareketle çalışma grubu belirlenmiştir. Yani çalışma grubunun farklı engel türlerinden ve kendini ifade etme becerisi yüksek kişilerden seçilmesi araştırma verilerinin daha nitelikli ve güvenilir kaynaktan elde edilmesi ile ilgilidir. Çalışma grubunun demografik özellikleri ile ilgili bilgiler Tablo 1'de verilmiştir. 
MENGİ

Engelli Bireylerin Gözüyle Özel Eğitim ve Rehabilitasyon Merkezlerindeki Ĕ̆itim Durumlarının İncelenmesi

Tablo 1. Katullmolarn Demografik Bilgileri

\begin{tabular}{|c|c|c|c|}
\hline Değişkenler & & $N$ & $\%$ \\
\hline \multirow{4}{*}{ Yaş } & $14-20$ & 5 & 27.8 \\
\hline & $21-27$ & 9 & 50 \\
\hline & $28-33$ & 2 & 11.1 \\
\hline & $34-55$ & 2 & 11.1 \\
\hline \multirow{2}{*}{ Cinsiyet } & Kadın & 2 & 11.1 \\
\hline & Erkek & 16 & 88.9 \\
\hline \multirow{6}{*}{ Eğitim Durumu } & Okula Gitmeyen & 4 & 22.2 \\
\hline & İlkokul & 2 & 11.1 \\
\hline & Ortaokul & 4 & 22.2 \\
\hline & Lise & 4 & 22.2 \\
\hline & Ön lisans & 2 & 11.1 \\
\hline & Lisans & 2 & 11.1 \\
\hline \multirow{3}{*}{ Gelir Durumu } & Düşük & 7 & 38.8 \\
\hline & Orta & 5 & 27.8 \\
\hline & Yüksek & 6 & 33.4 \\
\hline \multirow{4}{*}{ Engel Durumu } & Ortopedik Engelli & 8 & 44.4 \\
\hline & Görme Engelli & 6 & 33.4 \\
\hline & Serebral Palsi (SP) & 2 & 11.1 \\
\hline & Multiple Skleroz(MS) & 2 & 11.1 \\
\hline
\end{tabular}

Tablo 1'e bakıldığında katılımcıların \% 27.8’i 14- 20 yaş arasında, \% 50'si 21-27 yaş arasında, \% 11.1'i 28-33 ve \% 11.1’i de 34-55 yaşları arasında olduğu görülmektedir. Katılımcıların \% 11.1’i kadın, \% 88.9’u ise erkektir. Katılımcıların \% 22.2'sinin resmi eğitim kurumlarında okul okumadığı, \%11.1'inin ilkokul, \% 22.2'sinin ortaokul ve \% 22.2'sinin lise mezunu, \%11.1'inin ön lisans ve \%11.1'inin ise lisans mezunu olduğu görülmektedir. Katılimcıların \% 66.6'sının gelir durumunun düşük ve orta düzeyde, \% 33.4'ünün ise yüksek düzeyde olduğu belirlenmiştir. Katılımcılanın engel durumuna bakıldığında ise \% 44.4'ünün ortopedik, \% 33.4'ünün görme, \% 11.1'inin Serebral Palsi (SP) ve \%11.1'inin ise Multiple Skleroz (MS) tanısına sahip olduğu görülmektedir.

\section{Veri Toplama Araçları}

Araştırma, Ekim 2018'de başlamış olup Ocak 2019'de tamamlanmıştır. Araştırmada bireylere üç adet açık uçlu soru sorulmuştur. Ayrıca demografik bilgi formu kullanılmıştır. Bireylere görüşme formunda yer alan yarı yapılandırılmış sorular sorulmuştur. Araştırma sırasında görüşmeler kayıt cihazına kaydedilerek veriler elde edilmiştir. Bunun yanında, araştırma konusuyla ilgili doküman incelemesi yapılarak ilgili alanyazın taraması yapılmış ve görüşme soruları hazırlanmıştır. Ayrıca Özel Eŭitim ve Rehabilitasyon Merkezlerinde gözlemler yapılarak engelli bireyler hakkında bilgi elde edilmeye çalışılmıştır.

\section{Verilerin Analizi}

$\mathrm{Bu}$ araştırmada veriler araştırmacı tarafından kayıt cihazı dinleyerek katılımcılardan elde edilen sesli veriler tek tek yazıya geçirilmiştir. Daha sonra mevcut araştırma soruları ışı̆̆ında veriler dört farklı kategoriye göre sınıflandırılmış ve veriler arasında iç tutarlılık sağlanmıştır. Böylece veriler belli kategorilere uygun betimsel analize başvurularak sunulmuştur. "Betimsel analiz çeşitli veri toplama teknikleri ile elde edilmis verilerin daha önceden belirlenmiş temalara göre özetlenmesi ve yorumlanmasın içeren bir nitel veri analiz. türüdür" (Özdemir, 2010, s. 336). "Betimsel analizde, görüsülen ya da gözlenen bireylerin görüslerini çarpucı bir biçimde yansıtmak amaciyla doğrudan alıntılara sık sık yer verilir. Amaç, elde edilen bulgular düzenlenmis ve yorumlanmıs bir biçimde okuyucuya sunmaktır" (Y1ldırım ve Şimşek, 2016, s. 239).

\section{Bulgular}

Araştırma bulguları, üç temel araştırma sorusuna bağlı olarak dört farklı kategoride sunulmuştur. Bu kategorilere ilişkin bulgular sırayla aşağıda verilmiştir. 
Tablo 2. Katılimcularn Özel Eğitim ve Rehabilitasyon Merkęlerine Devam Durumu

\begin{tabular}{|c|c|c|}
\hline \multicolumn{3}{|c|}{$\begin{array}{l}\text { Değişken Adı/Kategori (Soru 1): Özel Eğitim ve Rehabilitasyon Merkezlerine Ne Kadar Süredir Devam } \\
\text { Etmektesiniz? }\end{array}$} \\
\hline Kodlar /Şıklar & $\begin{array}{l}\text { Kat1limc1 } \\
\text { (n)/(f) }\end{array}$ & Görüşler/Altın Örnekler \\
\hline Birkaç Aydır & $3 /(\% 16,7)$ & "2 ay var. Önceden çok okul vard gidemedim, kendim gitmiyordum..." (K7). \\
\hline Bir/İki Yildır & $5 /(\% 27,8)$ & "En fazla 2 senedir gidiyorum. İki sene de yoktur herbalde." (K4) \\
\hline Üç/Dört Yıldır & $8 /(\% 44,4)$ & "Ben buraya 2013'ten beri geliyorum 3-4 yal oldu..." (K14) \\
\hline Beş/Üstü Yıldır & $2 /(\% 11,1)$ & 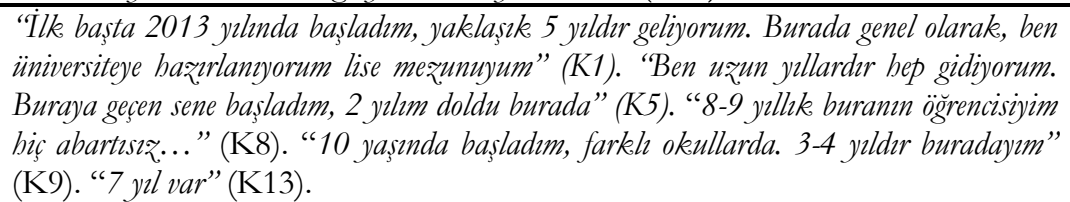 \\
\hline
\end{tabular}

Tablo 2'de katılımcıların \% 55,5’ten fazlası Özel Eğitim ve Rehabilitasyon Merkezlerine iki yıldan daha fazla sürede devam ettikleri bulgulamıştır. Bu süreçte engelli bireyler birden fazla farklı Özel Ĕğtim ve Rehabilitasyon Merkezine de gitmişlerdir.

Tablo 3. Katılımcılarn Özel Eğitim ve Rehabilitasyon Merkezlerindeki Ë̆itim Durumlar

\begin{tabular}{|c|c|c|}
\hline \multicolumn{3}{|c|}{$\begin{array}{l}\text { Değişken Adı/Kategori (Soru 2): Özel Eğitim ve Rehabilitasyon Merkezinde aldığınız eğitim hakkında ne } \\
\text { söyleyebilirsiniz? }\end{array}$} \\
\hline Kodlar /Ş1klar & $\begin{array}{l}\text { Kat1limc1 } \\
(\mathrm{n}) /(\mathrm{f})\end{array}$ & Görüşler/Altın Örnekler \\
\hline Fizik Tedavi & $\begin{array}{l}12 \\
(\% 66,7)\end{array}$ & 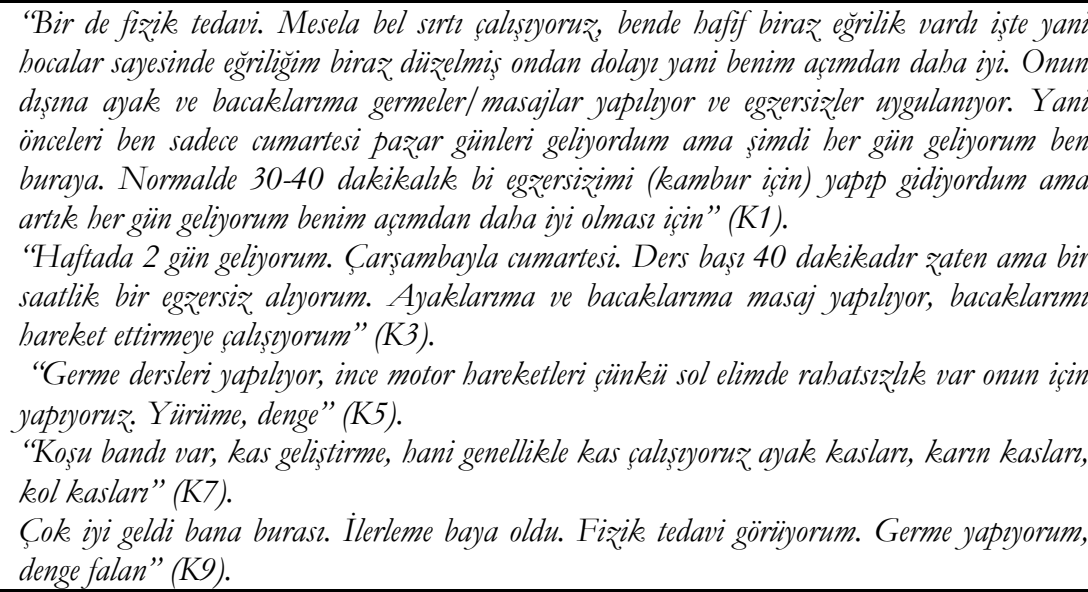 \\
\hline $\begin{array}{l}\text { Kabartma } \\
\text { ve Baston } \\
\text { Eğitimi }\end{array}$ & $\begin{array}{l}6 \\
(\% 33,3)\end{array}$ & 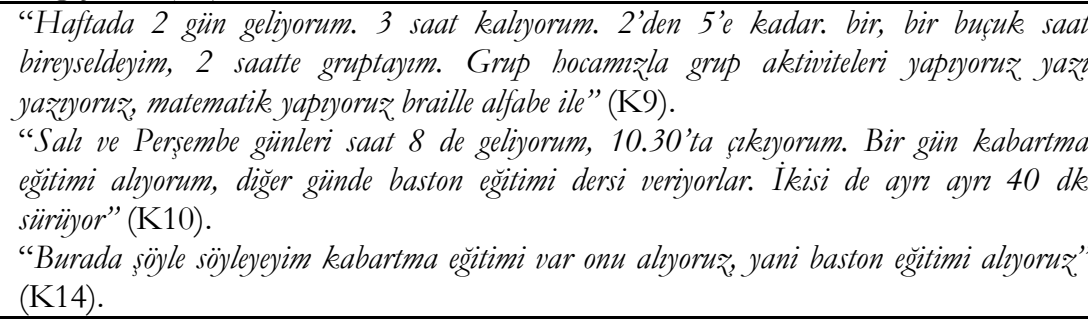 \\
\hline Bireysel Dersler & $\begin{array}{l}18 \\
(\% 100)\end{array}$ & 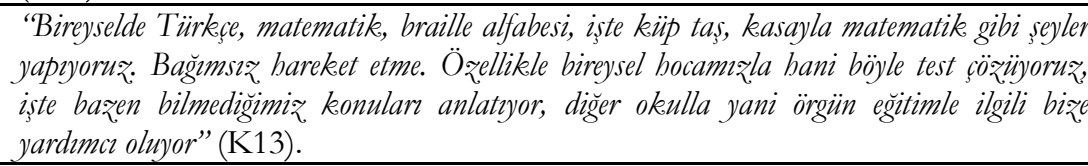 \\
\hline Grup Eğitimi & $\begin{array}{l}18 \\
(\% 100)\end{array}$ & 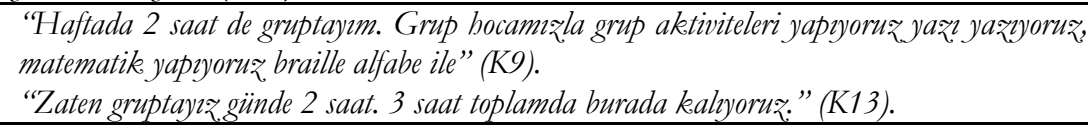 \\
\hline $\begin{array}{l}\text { Sinavlara } \\
\text { Yönelik } \\
\text { Ë̆gitimler }\end{array}$ & $\begin{array}{l}6 \\
(\% 33,3)\end{array}$ & $\begin{array}{l}\text { "Burada genel olarak, ben üniversiteye hazırlaniyorum lise mezunuyum. Bi hocamdan } \\
\text { matematik geometri dersleri alyyorum rehabilitasyon merkezinde" (K1). } \\
\text { "Memurluğa hazırlaniyorum o derslerle ilgili de eğitim aliyorum. Kitap okuyorlar bize. } \\
\text { Bizde o kitaplar dinleyip soru çözüyoruz" (K14). }\end{array}$ \\
\hline
\end{tabular}


Tablo 3’te katılımcılar Özel Eğitim ve Rehabilitasyon Merkezlerinde altıkları eğitimler ile ilgili görüşleri alt kategoriler şeklinde verilmiştir. Tüm katılımcıların hem grup hem de bireysel olarak eğitim aldıkları, engel türlerine göre fizik tedaviler gördükleri, görme engelli bireylerin kabartma yazı ve baston eğitimlerini aldıkları, bazı engelli bireylerin de sınavlara yönelik eğitim aldıkları tespit edilmiştir. Dolayısıyla engelli bireylerin Özel Eğitim ve Rehabilitasyon Merkezlerinde engel türlerine ve bireysel ihtiyaçlarına uygun eğitim aldıkları görülmektedir. Örneğin, görme engelli birey daha çok Braille alfabesine ve baston kullanmaya ilişkin dersler alarak bağımsız hareket etme çalışmaları yaparken, MS'li katılımcılar daha çok masaj, germe ve egzersizlere ilisskin eğitimler almaktadırlar. Ortopedik engelli ve SP'li katılımcılar ise yürüyüş, koşu bandı, germe, bel/sırt çalışma ve fizik tedavi gibi çalışmalar yoluyla eğitim almaktadırlar. Katılımclar Türkçe ve Matematik dersler gibi akademik ve müzik, beden eğitimi ve görsel sanatlar gibi yeteneklerine uygun dersleri de aldıkları bulgulamıştır.

Katılımcıların hemen hepsi haftada iki gün ve 40-45 dakikalık eğitimler için Özel Eğitim ve Rehabilitasyon Merkezine gitmektedirler. Katılımcilar daha çok fiziksel egzersizler, fizik tedavi, baston eğitimi gibi eğitimleri grup eğitimi kapsamında aldıklarını ifade etmişlerdir. Ayrıca katılımcıların bireysel eğitimler için aldıkları eğitimler ise 60-90 dakikalık bir süreyi ve Türkçe, Matematik gibi akademik beceriyi gerektiren eğitimleri kapsamaktadır.

Katılımcılar, Özel Eğitim ve Rehabilitasyon Merkezinde aldıkları eğitimin tekranını ev ödevi şeklinde de yapmak zorunda kaldıklarını belirtmişlerdir. Katılımcıların önemli bir kısmı ev ödevleri sayesinde egzersiz yapma imkânına sahip olduğunu ifade etmiştir. Ancak bazı katılımcıların ev ödevleri yaparken ölçüyü kaçırdıkları yani evlerinde egzersiz yaparken bazen bundan aşırıya kaçtıkları için faydadan daha çok zarar gördükleri, bu yüzden de eğitimcilerin verdiği egzersiz sayısının dışına çıkılmaması gerektiğini söylemişlerdir. Katılımcıların bu hususa ilişkin görüşleri aşağıda verilmiştir;

"Şimdi örneğin buradaki hocalarm baæ seyleri bana ögretiyor sonra evde de bunlar yap diyorlar. Onlar yapıyorum, egzersizlerimi yapryorum. Yani şu var şimdi bir hastann kendi kafasina göre hareket etmemesi laz̧m. Örneğin ben baž egzersiz̨leri kendim yapmaya çalş̧tm ama zarar gördïm. Ama hocann verdiği egzersizleri aym şekilde uygularsam çok fayda görïyorum. Ama ben işte hoca bana diyor 20 defa şu egzersizi yap ama ben 40 defa yapiyorum, 50 defa yapiyorum. E o zaman zarar olur. Onun için bastanm buna çok dikkat etmesi larm" (K11).

"Evde veriliyor da ben kendim uygulamyorum diyebilirim. Verildiği zaman örnek vereyim kabartma yaz? üzerinden siiir yazmake veya bir cümle, bir şeyler yazmak için ödev veriliyor" (K14).

"Burada yaptiğım egzersizleri diyorlar evde de yap aynısm. Tabi ben çok çalsstğğm için firsat bulamiyorum, firsat bulduksca yapiyorum. Zamanm yetmiyor yani. Hem 2 çocuğum var evliyim, işe gidiyorum, firsat buldukça yapiyorum" (K5).

Tablo 4. Özel Ĕ̈itim ve Rehabilitasyon Merkezlerindeki Eğitimin Faydalar

\begin{tabular}{|c|c|c|}
\hline \multicolumn{3}{|c|}{$\begin{array}{l}\text { Değişken Adı/Kategori (Soru 3): Özel Eğitim ve Rehabilitasyon Merkezlerinde Aldığınız Eğitimin nasıl bir } \\
\text { faydasını gördünüz? }\end{array}$} \\
\hline $\begin{array}{l}\text { Kodlar } \\
\text { /Şı1klar } \\
\end{array}$ & $\begin{array}{l}\text { Kat1lımc1 } \\
\text { (n)/(f) }\end{array}$ & Görüşler/Altın Örnekler \\
\hline $\begin{array}{l}\text { Yürümemi } \\
\text { sağlıyor }\end{array}$ & $\begin{array}{l}2 \\
(\% 11,1)\end{array}$ & 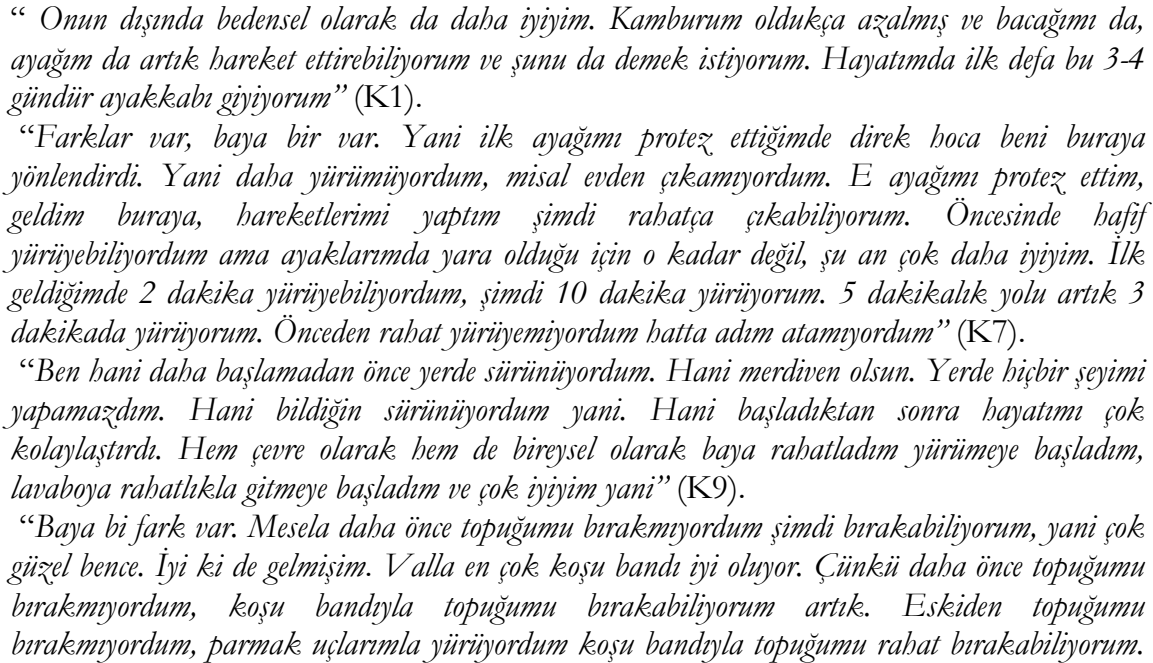 \\
\hline
\end{tabular}




\begin{tabular}{|c|c|c|}
\hline & & 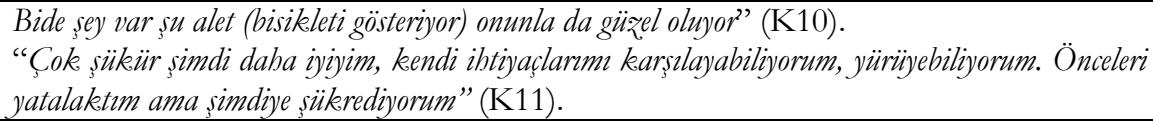 \\
\hline & $\begin{array}{l}6 \\
(\% 33,3)\end{array}$ & 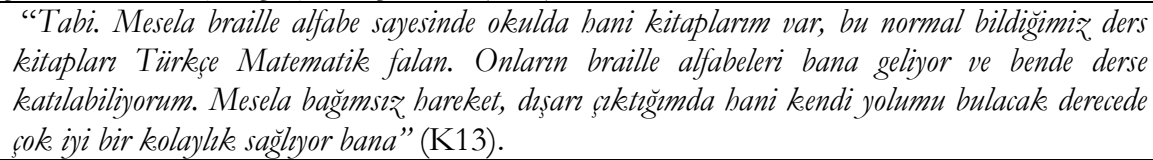 \\
\hline $\begin{array}{l}\text { Engelimde } \\
\text { iyileşme } \\
\text { sağladı }\end{array}$ & $\begin{array}{l}7 \\
(\% 38,9)\end{array}$ & 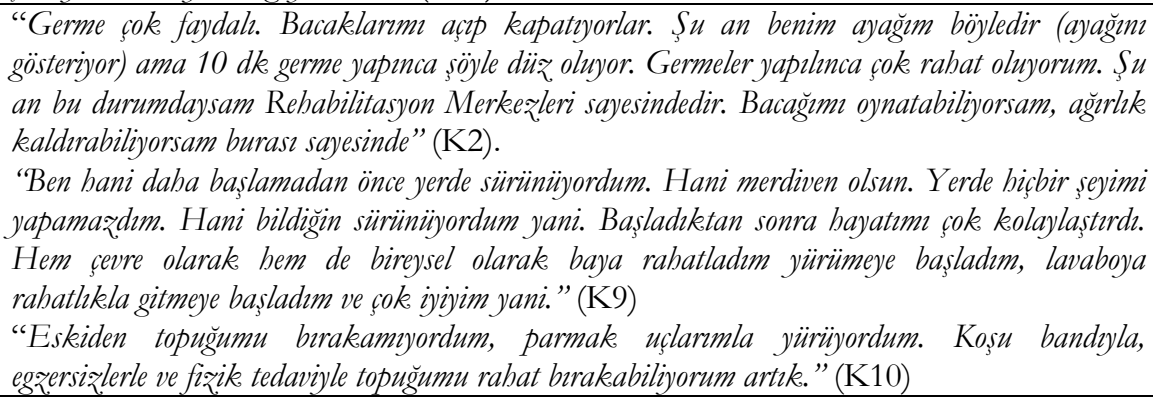 \\
\hline $\begin{array}{l}\text { Kasılmamı } \\
\text { engelliyor ve } \\
\text { ağrılarımı } \\
\text { azaltıyor }\end{array}$ & $\begin{array}{l}7 \\
(\% 38,9)\end{array}$ & 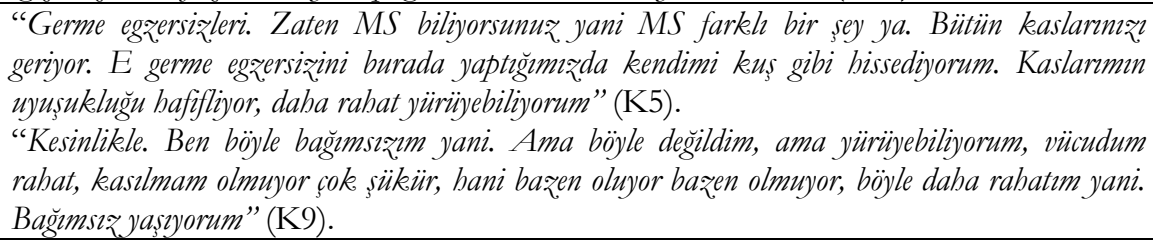 \\
\hline & $\begin{array}{l}4 \\
(\% 22,2)\end{array}$ & 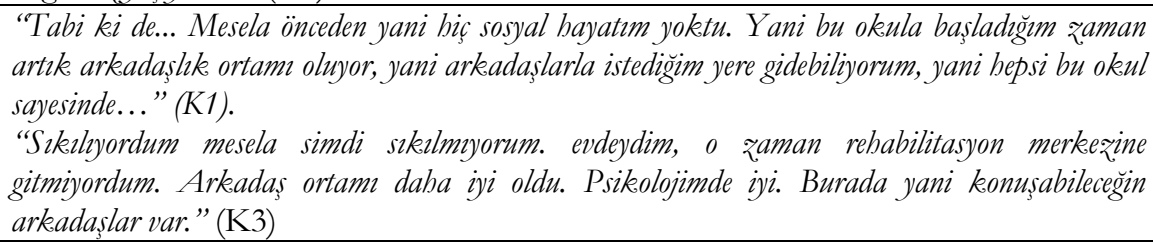 \\
\hline $\begin{array}{l}\text { Engelimi } \\
\text { kabullendim }\end{array}$ & $16,7)$ & 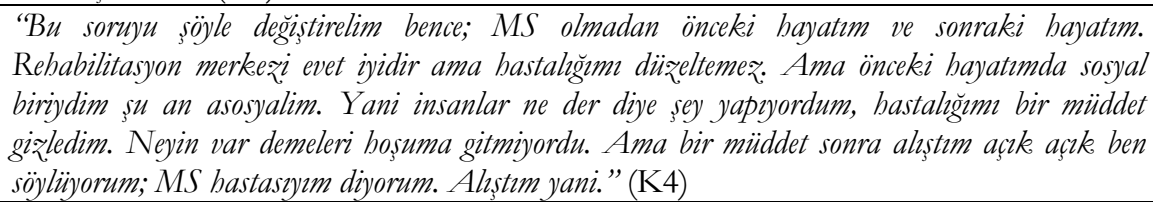 \\
\hline $\begin{array}{l}\text { Özgüven } \\
\text { kazandım }\end{array}$ & & $\begin{array}{l}\text { "Cok olumlu șeyler oldu, ben müziğe rehabilitasyonla başladim. O anlamda kendimi gelistirmemi } \\
\text { sağladl. Önceden bu kadar girișken değildim, bana soru sorulduğunda pek cevap veremezdim, hani } \\
\text { bu da biraz özgüven meselesi. Özgüvenimi sağlad, aynca bayatımda o kadar kolay değildi." } \\
\text { (K13) }\end{array}$ \\
\hline $\begin{array}{l}\text { Bir farklilık } \\
\text { olmadı }\end{array}$ & $3(\% 16,7)$ & "Hiçbir sey değismedi. Her zaman böyleyim." (K16) \\
\hline
\end{tabular}

Tablo 4'te katılımcıların, Özel Eğitim ve Rehabilitasyon Merkezlerinde aldıklan eğitimler sonucunda braille alfabe ile okumaya geçebildikleri, psiko-motor becerilerinin (ayak ve kol kaslarının) geliştiği, bu kasların kullanımının işlevsel bir boyut kazandığına dair görüşleri olmuştur. Ayrıca, Özel Eğitim ve Rehabilitasyon Merkezlerine gitmenin katılımcılar için sosyal çevre ve arkadaş ortamı oluşturduğu, evden çıkıp farklı bir ortama girmenin, farklı insanlarla tanışma firsatı sunduğu, günlük yaşamlarını olumlu etkilediği, bağımsız yaşam becerilerini geliştirdiği, görme engelli bireylerin braille alfabesi ile derse rahatça katılabildikleri gibi bir dizi bulguya ulaşılmıştır. Örneğin, K5'in aşağıdaki görüşleri bu konudaki bulgulara projeksiyon tutmaktadır.

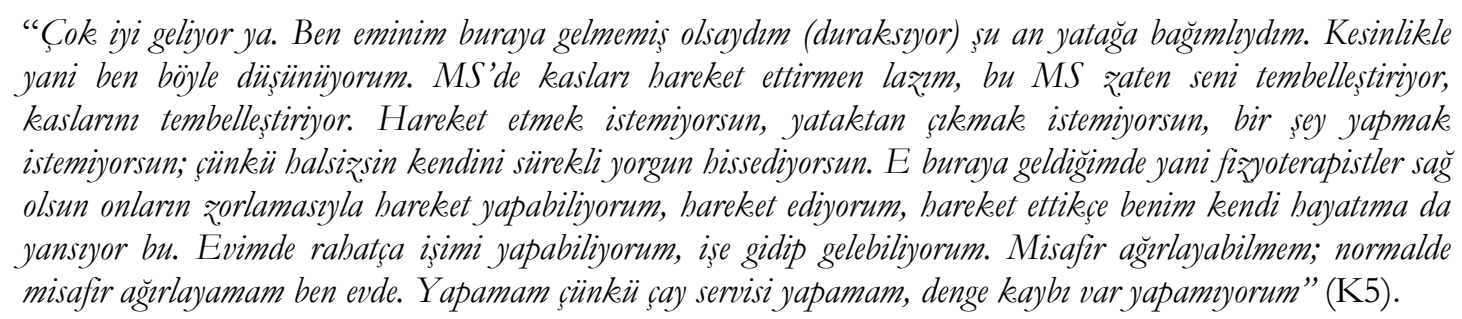

Özel Eğitim ve Rehabilitasyon Merkezlerinin katılımcıların yaşamları üzerine doğruda olumlu etkiler bıraktığı görülmektedir. Çünkü daha önceden evden hiç çıkmayan engelli bireyler bu kurumlar sayesinde dış yaşamla bir nebze de olsa bağ kurabilmiştir. Böylece bu kurumlar aracıllğıyla kendilerine belli bir sosyal 
çevre edinebilmişlerdir. Ayrıca engellilik olgusunun sadece kendilerinin sorunu olmadı̆̆ını toplumsal bir sorun olduğunu bu kurumlar sayesinde anlayabilmişlerdir. Hatta önceden engel durumundan dolay1 hallerinden şikâyetçi olanlar kendilerinden daha ağır engelli bireyleri gördükleri için hallerine şükrettiklerini belirtmişlerdir. K1 ve K2'nin bu konu ile ilgili görüşleri aşağıda verilmiştir.

\begin{abstract}
"Cok çok fark var. Önceki hayatımda bic evden dişar çıkamiyordum. Sürekli eve kapalyydım yani kendimi kapatmıstım hep. Sonrasında da zaten burada okula başladiğım zaman sosyal hayatım oldu, arkadas ortamım oldu. Şunu da diyebilirim önceleri zaten sürekli halimden sikâyetçiydim, yani hani (duraksiyor) anlarsinız. zaten. İste o yüzden öyle sikêayetçiydim halimden. Sonra geldim buraya bazı arkadaşlar görüyorum halime sïkerediyorum. Yani diyorum ki ben böyleysem zaten Allab beni bunun için yaratmıs onun için (duraksıyor) yani öyle. Onun dısında kendime olan güvenim artı yalnı olmadiğım biliyorum artık. Bedensel olarak da kamburumda düzelme var, bacaklarmi, ayaklarmı bareket ettirebiliyorum” (K1).
\end{abstract}

"Buraya gelmeden önceki hayatım anlatayım. Hani affedersin bir hayvandan farkımız yoktu. Bundan 15 yul öncesinde evimdeyim, tekerlekli sandalye yok, bahçede emekliyorum. Yemin ederim o zamanki hayatım hatorlaynca kendimi zar zor tutuyorum üzülüyorum. Calı giriyordu, cam giriyordu dizlerime. Kan akzyordu ama yaram saran kimse yok. Nasıldım diyeyim, el arabasiyla batırlyorum ben de ăğrm. Ablam kardeşim beni tassyamyyordu. El arabasinda bayramlar geziyordum. Hani o günleri çok hattrlyorum. Anne baba zaten yok (Allah rahmet etsin, Araştırmac1). Allah rą̧ olsun. Abim yardimc oluyor ama insanın annesi babası olması çok farkh. Bir hayvan, yaurusunu acı içinde görürse onun bile içi acır. Biz̧im komşular kapıdan geçiyordu köpek muamelesi yapan vardl, hor gören vardl, bu hastaliğım yüzüme vuran vardı. Üzülüyordum, üqülmemek elde değil ama insan büyüyünce olgun olduğu zaman gecmisindekine geride kalmıs insanlar diyor. Bana engelli dediler, bana bebek dediler, baya hor gördüler beni. Emin ol bak, engelli nasil engellidir bunu anlatabilirim: engelli, bir basamă̆ aşamayandır, kendi başına araca binemeyen engellidir, kendi bașına bir şey yapamazsa engellidir değil mi? Pekâlâ biz engelliler dünyay kendimize göre yapsaydık engelliler kim olurdu? Sizler olacaktını:. Şimdi sırf bu kadarcık basamağı aşamyoruz diye engelli oluyoruz. Basamak engeldir, biz engelli değiliz:" (K2).

Tablo 5. Katılımolarn Özel Eğitim ve Rehabilitasyon Merkęleri Hakkındaki Görüsleri

\begin{tabular}{|c|c|c|}
\hline Kodlar /Şıklar & $\begin{array}{l}\text { Katılimci } \\
\text { (n) } \\
\text { /Kodlar } \\
\text { (f) }\end{array}$ & Görüşler/Altın Örnekler \\
\hline $\begin{array}{l}\text { Olumlu } \\
\text { görüşler } \\
\text { - Kabullenme } \\
\text { - Sosyalleşme } \\
\text { - Psikolojik } \\
\text { Rahatlama } \\
\text { - Özgüven } \\
\text { Artması }\end{array}$ & $\begin{array}{l}13 \\
(\% 72,2)\end{array}$ & 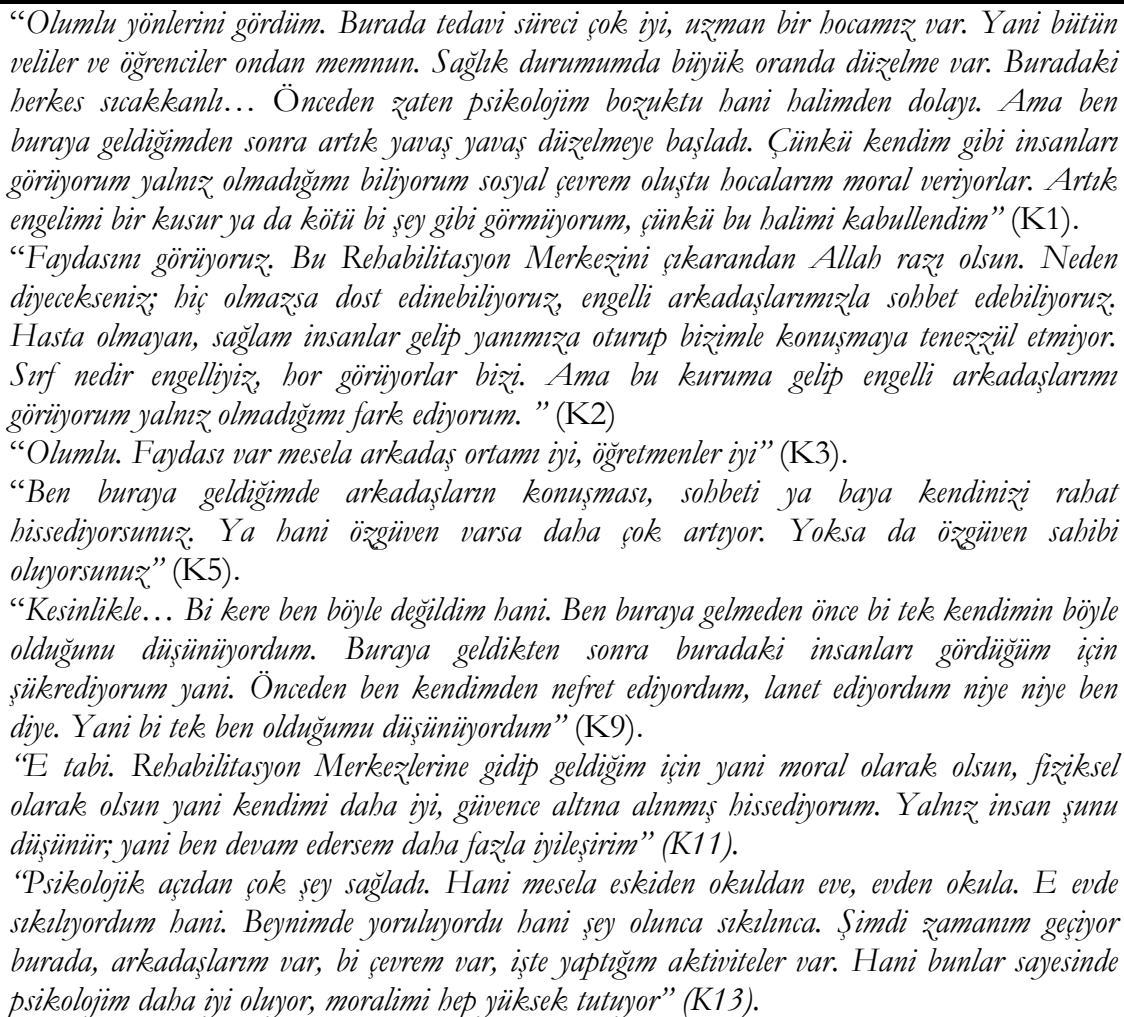 \\
\hline
\end{tabular}




\begin{tabular}{|c|c|c|}
\hline $\begin{array}{l}\text { Olumsuz } \\
\text { görüşler } \\
\text { - Fayda } \\
\text { görmeme } \\
\text { - Kurumların } \\
\text { Engellerine } \\
\text { uygun } \\
\text { uyarlanamaması }\end{array}$ & $2(\% 11,1)$ & 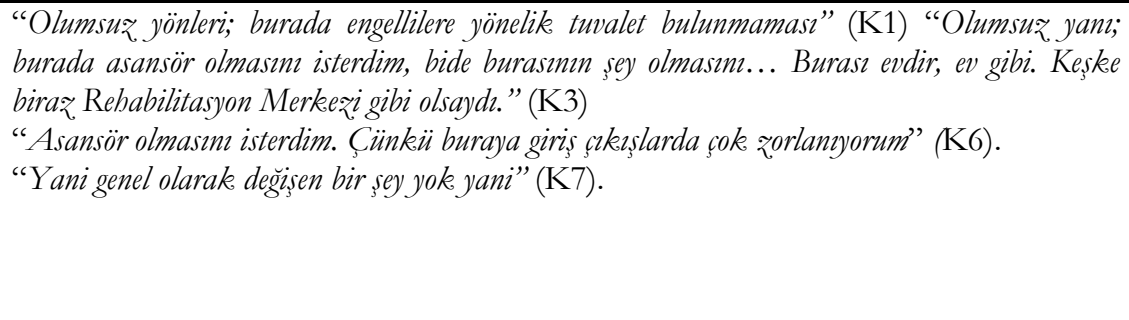 \\
\hline $\begin{array}{l}\text { Fikir } \\
\text { belirtmeyen }\end{array}$ & $3(\% 16,7)$ & "Söyleyecek bir seyim yok." (K18) \\
\hline
\end{tabular}

Tablo 5'te Katılımcıların \% 72,2'si Özel Eğitim ve Rehabilitasyon Merkezleri ile ilgili olumlu yönden görüş beyan etmişleridir. Olumlu gönde görüsş beyan eden katıllmcılar, Özel Eğitim ve Rehabilitasyon Merkezlerine gitmeden önce engellerinden dolayı psikolojilerinin bozuk olduğunu, dünyadaki tek engellinin sadece kendileri olduğunu düşündüklerini, yalnızlık çektiklerini, engellerini kusur ya da kötü bir şey olarak gördüklerini ifade etmişlerdir. Özel Eğitim ve Rehabilitasyon Merkezlerine gittikten sonra ise, bakış açılarının olumlu yönden değiştiğini, kendileri gibi engelli bireyleri gördükleri için hallerine şükrettiklerini, yalnızlık çekmediklerini, özgüven kazandıklarını, konuşup dertleşebilecek insanlar bulduklarını ve özgüven kazandıklarını dile getirmişlerdir. Ayrıca katılımcılar Özel Eğitim ve Rehabilitasyon Merkezleriyle ilgili; K6'nın belirtiği gibi "Buradan memnunum. Hiç burada bi sıkentım olmadi" gibi olumlu görüss belirtmişlerdir. Yani tedavi süreçlerinin iyi olduğu, eğitimcilerin ilgili oldukları ve sıcakkanlı davrandıkları, engelli bireylerin birbirleriyle dostluk, arkadaşlık kurabildikleri ve kendilerini yalnız hissetmedikleri bir yer olduğu şeklinde olumlu görüşlerini belirtmişlerdir. Katılımcılar, Özel Eğitim ve Rehabilitasyon Merkeziyle ilgili olumsuz görüşler de belirtmişlerdir. Katıllmcılardan biri Özel Eğitim ve Rehabilitasyon Merkezinin engellilere yönelik tuvaletinin bulunmamasını, bir diğerinin gittiği kurumun mimari yap1 olarak ev gibi olduğunu ve normal eğitim merkezi gibi olmadığını, bir diğeri ise gittiği kurumunun asansörünün bulunmamasını olumsuz görüş olarak belirtmiştir. Dolayısıyla katılımcılar olumsuz görüş belirtirken sadece gittikleri kurumun fiziki yapısının engelli bireylere uygun olmadığını eleştirmişlerdir.

\section{Tartışma, Sonuç ve Öneriler}

$\mathrm{Bu}$ araştırmada engelli bireylerin Özel Eğitim ve Rehabilitasyon Merkezlerine ne kadar sürede gittikleri, buralarda ne tür eğitimler aldıkları, aldıkları eğitimin hayatlarını nasıl etkilediğine dair bulgu ve sonuçlara ulaşılmıştır.

Araştırmanın birinci araştırma sorusuna bağlı olarak ulaşılan sunuca bakıldığında; katılımcıların büyük bir kısmı Özel Eğitim ve Rehabilitasyon Merkezlerine en az iki en fazla on iki yll gittikleri ve çoğu katılımcının birden fazla merkezde eğitim aldığ1 sonucuna ulaşmıştır. Ancak özel eğitim hizmetlerini sunan eğitim kurumlarının ülkemizde yeteri sayıda olmadığı bir gerçektir. Çünkü Türkiye'de engelli bireylerin sayısı giderek artmaktadır. Sosyal devlet gereği, devlet engelli bireylere eğitimde eşit imkân ve firsat sunabilmek için "yeterli saynda okul açarak eğitim imkânlarm ženginleştirmeli" (Doğru, Özlü, Kançeşme ve Doğru, 2014, s. 287) sonucuna da ulaşılmıştır.

Araştırmanın ikinci araştırma sorusuna bağlı olarak ulaşılan sunuca bakıldığında; katılımcıların Özel Eğitim ve Rehabilitasyon Merkezlerinde hem grup hem de bireysel olarak eğitim aldıkları, engel türlerine göre fizik tedaviler gördükleri, görme engelli bireylerin kabartma yazı ve baston eğitimlerini aldıkları gibi bazı tespitler yapılmıştır. Öncül (2014) “Türkiye'de Erken Cocuklukta Özel Eğitim İle Illgili Yapullşs Makalelerin Gözden Geçirilmesi” çalışmasında erken çocukluk özel eğitim sürecinde belirlenen hedef grupların, hedef becerilerin, program ve uygulamaların farklılaştırılması ile çocuklara, öğretmenlere ve ailelere önemli oranda katk1 sağladığı sonucuna ulaşılmışır.

Katılımcıların genel olarak haftanın iki günü eğitim aldıkları, ortalama 40-45 dakika grup eğitimi ve 40-45 dakikaya kadar da bireysel eğitim çalışmalar yaptıkları tespit edilmiştir. Ayrıca farklı sosyal-kültürel etkinliklerle bireylerin gelişimi desteklenmektedir. Özel Eğitim ve Rehabilitasyon Merkezlerinde grup eğitimi ve etkinliklerle engelli bireyin akranlar ve toplumla kaynaşması amaçlanmaktadır. Böylece engelli bireylerin topluma bağımsız katılımı desteklenmektedir. Akçamete de (2009) "Engelli Öğrenciler İçin Kaynaştırma Modeli Geliştirme Projesi" adlı çalışmasında genel ve özel eğitimciler arasında oluşturulacak etkili bir işbirliği yaklaşımıla kaynaştırma ortamlarına yerleştirilmiş engelli öğrencilerin başarılarını ve topluma 
bağımsız katılımlarını arttıran bir model geliştirme amacına ilişkin sonuçlara ulamıştır. Sülün ve Girli’nin

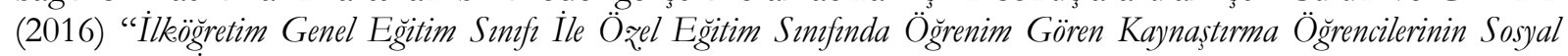
Becerilerinin İncelenmesi” çalışmalarında ilköğretim düzeyinde farklı kaynaştırma uygulaması türlerinden yararlanan zihinsel yetersiz öğrenciler sosyal beceri açısında gelişim gösterdiği sonucu çıkmıştır. Ayrıca Özen ve Ergenekon'un (2011) “Özel Eğitimde Etkinlik. Temelli Ögretim Uygulamalar" adlı çalışmaları da erken eğitim programlarına devam eden değişik özür ve yaş gruplarındaki gelişimsel yetersizliği olan çocuklara etkili öğretim sunmada etkinlik temelli öğretime dayalı öğretim uygulamalarına yer vermesinin engelli bireyleri geliştirdiğine dair sonuca ulaşmıstır.

Araştırmanın üçüncü araştırma sorusuna bağlı olarak ulaşılan sunuca bakıldığında; Katılıcıların Özel Eğitim ve Rehabilitasyon Merkezlerinde aldıkları eğitimler sonucunda braille alfabe ile okumaya geçebildikleri, psiko-motor becerilerinin geliştiği, bu kasların kullanımının işlevsel bir boyut kazandığ1 yönünde verilere ulaşılmıştır. Katılımcıların, Özel Eğitim ve Rehabilitasyon Merkezlerine gitmenin onlar için sosyal çevre ve arkadaş ortamı oluşturduğu, günlük yaşamlarını olumlu etkilediğini, bağımsız yaşamlarına ve kimseye muhtaç olmadan ihtiyaçlarını giderebilmelerine yardımcı olduğu sonucuna ulaşılmışır. Ayrıca katılımcıların Özel Eğitim ve Rehabilitasyon Merkezlerinde aldıkları eğitimlerden memnun kaldıkları sonucu ortaya çıkmıştır. Dolayısıyla MEB'na bağı Özel Eğitim Kurumları engelli bireylere haftada 30 saat özel eğitim verirken Özel Eğitim ve Rehabilitasyon Merkezleri haftada engelli bireylere 2 saat eğitim vermesine rağmen bu kurumlara giden engelli bireylerin kurumlara yönelik memnuniyetlerinin olması önemli bir sonuca işarettir. Çünkü bu kurumlar sosyal yaşam içinde yalnızlık ve dışlanmışlık sarmalından kurtulmak isteyen engelli bireyler için adeta bir can simidi görevini görmektedir. Engelli bireyler bu tarz kurumlar sayesinde sosyal yaşama yeniden tutunma imkânı yakalamaktadırlar. Engelli bireyler engelliliğin sosyal bir olgu olduğu gerçeğini de bu kurumlar sayesinde fark etmektedirler. Aynı zamanda engelli bireyler için bu kurumlar, geçmiş yaşamlarındaki acıları unutmanın, şimdiki yaşamlarını anlamlı kılmanın ve geleceğe umutla bağlanmanın birer aracı olarak görüldüğü düşünülmektedir.

Gündüz ve Akın’ın (2015) “Türkiye'de Devlet Okullarndaki Özel Ë̈̆timle İlgili Sorunlar ve Çözüm Önerileri” çalışmalarında Türkiye'de özel eğitim alanında devlet okullarında farklı sorunların bulunduğu, özel eğitimde ise ortam düzenlemesi ve ögretmen kalitesi gibi sorunların daha yoğun olduğu belirlenmiştir. Benzer sonuçlara bu araştırmada da ulaşılmıştır. Bu araştırmada da devlet okullarında engelli bireyin doğrudan engelline yönelik tedavi ve terapi uygulamalanndan ziyade daha çok akademik içerikli eğitimlerin verilmesi katılımcılar tarafinda bir sorun olarak ifade edilmiştir. Diğer taraftan Özel Eğitim ve Rehabilitasyon Merkezlerinde ise daha çok fiziki mekânda erişebilirlik ve kurumların fiziki donanımıyla ilgili sorunlar dile getirilmiştir. Dolayısıyla gerek resmi gerekse özel özel eğitim kurumlannda engellilerin belli sorunlar yaşadığına dair sonuçlara ulaşılmıştır. Ayrıca katılımcıların her iki farklı kuruma yönelik beklentilerine sorunların giderilmesi yönünde olmuştur. Çetin (2017) "Özel Gereksinimli Bireylerin Terciblerinin Değerlendirilmesi" çalışmasında engelli bireylerin bağımsız yaşamada, sorumluluk almada onlara seçim hakkı verilmesi gerektiği gibi sonuçlara ulaşılmıştır. Bu araştırmada da benzer sonuçlara ulaşılmıştır. Son olarak bu araştırmayı engellilere yönelik yapılan diğer araştırmalardan farklı kılan yönü resmi örgün eğitim kurumlarında özel eğitim firsatı almayan engelli bireylerin Özel Özel Eğitim ve Rehabilitasyon Merkezleri yoluyla haftada ancak 2 saatlik eğitimlerle yaşama tutunma serüvenlerine projeksiyon tutmasıdır. Dolayısıyla Türkiye'de bu konudaki araştırmanın yok denecek kadar az olması bu çalışmanın da önemini ortaya koymakta ve yeni araştırmalara davetiye çıkarmaktadır.

Engelli bireylerin eğitimi son derece önemli bir konudur. Bu nedenle onlara sunulan eğitim hizmetlerinin, hizmetin sunulduğu alanın ve eğitimcilerin üzerinde titizlikle durulması gerekir. Bu eğitim hizmetini sağlayan kurumların başında ise Özel Eğitim ve Rehabilitasyon Merkezleri gelmektedir. Özel Eğitim ve Rehabilitasyon Merkezlerinin fiziki şartlarının iyi olması, eğitimcilerin ise uzmanlardan seçilmesi gerekmektedir. Dolayısıyla, Özel Eğitim ve Rehabilitasyon Merkezlerinde engelli bireylerin bireysel ihtiyaçlarına uygun makul uyarlamalara sahip olması önerilmektedir. İleri araştırmalar için ise Türkiye'nin farklı illerinde bulunan araştırmacılar, Rehberlik Araştırma Merkezi yetkilileri ve ìl Milli Eğitim Müdürlüklerinde özel eğitimden sorumlu birim yetkililerinin Özel Eğitim ve Rehabilitasyon Merkezlerine yönelik araştırma yapmaları önerilmektedir. Ayrıca bu kurumların fiziki mekânda ya da bilgiye erişim imkânlarının iyileştirilmesi için ve bu kurumlarda daha nitelikli eğitimcilerin çalıştırılması için gerekli denetimlerin sıklaştırılması önerilmektedir. 


\section{Kaynakça}

Akbulut, S., Özgül, H. ve Tezcan, T. (2014). Mevzuattan uygulamaya engelli hakları izleme raporu 2013. İstanbul.

Akçamete, G. A. (2009). Özel gereksinimli öğrenciler için kaynaştırma modeli geliştirme projesi. Ankara Üniversitesi Bilimsel Araştırma Projeleri. Ankara.

Akçamete, G. (Ed.). (2010). Genel eğitim okullarnda özel gereksinimi olan ögrenciler ve öẓel eğitim (6. Bask1). Ankara: Kök Yayıncilik.

Ataman, A. (Ed.) (2009). Öz̨el gereksinimli çocuklar ve özel eğitime giriş. Ankara: Gündüz Eğitim ve Yayınc1l1k.

Aydın, S. (2007). Özel eğitim kurumlarnda yaşanan eğitsel-yönetsel yetersizlikler ve çözüm önerileri (Yüksek Lisans Tezi). İstanbul Sabahattin Zaim Üniversitesi Sosyal Bilimler Enstitüsü, İstanbul.

Aykara, A. (2010). Kaynastırma eğitimi sürecindeki bedensel engelli ögrencelerin sosyal uyumlarm etkileyen etmenler ve okul sosyal hizmeti (Yüksek Lisans Tezi). Hacettepe Üniversitesi, Sosyal Bilimler Enstitüsü, Ankara.

Berg, B. (2001). Qualitative research methods for the social sciences. USA: Allyn\&Bacon.

Burcu, E. (2013). Engeli gençlik ve sosyal riskler. Genclik. Arastormalar Dergisi, 1(2), 30-45.

Burcu, E. (2015). Engellilik sosyolojisi. Ankara: Anı Yayınc1lı.

Çetin, M. E. (2017). Özel gereksinimli bireylerin tercihlerinin değerlendirilmesi. Ankara Üniversitesi Eğitim Bilimleri Fakültesi Örel Eğitim Dergisi, 18(11), 309-328.

Demirel, Ö. ve Kaya, Z. (Ed.). (2012). Eğitim bilimine giriş (7. Baskı). Ankara: Pegem Akademi Yayınevi.

Fatma, N. S. ve Yasemin, B. (Ed.), (2015). Nitel araștırma (Yöntem, teknik, analiz ve yaklaşımlar). Ankara: Anı Yayıncilık.

Giddens, A. (2006). Sociology, $5^{\text {th }}$ Edition, Cambridge: Polity Press.

Güleryüz, Ş. (2009). Kaynaştırma Eğitimine Devam Eden Engelli Öğrencilerin Akranlar İle İlişkeilerinde Karşılaştıklar Sorunlarn degerlendirilmesi, Yüksek Lisans Tezi, Konya.

Güven- Arslan, ذ̇. (2014). Öz̨el eğitim ve rehabilitasyon merkęlerindeki müsteri memnuniyeti: Muğla-menteşe örneği (Yüksek Lisans Tezi). Muğla Sitkı Koçman Üniversitesi Sosyal Bilimler Enstitüsü, Muğla.

Işı1k, H. (2013). Engellilik sorununa kelami bir yaklaşım. Ekev Akademi Dergisi, 17(57), 1-22.

İslamoğlu, A. H. ve Alnıaçık, Ü. (2013). Sosyal bilimlerde araştırma yöntemleri. İstanbul: Beta Basım Yayım Dağıtım.

Kulaksızoğlu, A. (Ed.). (2003). Farkh gelişen çocuklar. İstanbul: Eplison Yayıncilık.

Mengi, A. (2016). Özel gereksinimli çocuk hakları. İçinde Z. Merey (Edt.). Çocuk hakları. Ankara: Pegem Akademi Yayınevi.

Mevlüt, G. ve Akın, A. (2015). Türkiye'de devlet okullarındaki özel eğitimle ilgili sorunlar ve çözüm önerileri. Ĕğtim ve Öğretim Arastırmalar Dergisi, 4(2), 93-94.

Okan, K. ve Okan, N. (2006). Evimizdeki engelli. Ankara: Milli Eğitim Sağlık Eğitimi Vakfı (MESEV).

Oymak, V. (1997). Zekê engelli çocuklarn yetiştirilmesi. Ankara: Sabev.

Öncül, N. (2014). Türkiye'de erken çocuklukta özel eğitim ile ilgili yapılmış makalelerin gözden geçirilmesi. International Journal of Early Childhood Special Education (INT-JECSE), 6(2), 276.

Özbey, Ç. (2009). Özel çocuklar ve terapi yöntemleri. İstanbul: İnkılap Kitabevi.

Özdemir, M. (2010). Nitel veri analizi: Sosyal bilimlerde yöntembilim sorunsalı üzerine bir çalışma. Eskişsebir Osmangazi Üniversitesi Sosyal Bilimler Dergisi, 11(1), 323-343.

Punch, K. F. (2005). Sosyal araştırmalara giriş-nicel ve nitel yakelaşımlar (Çev: D. Bayrak, H. B. Arslan, Z. Akyüz). Ankara: Siyasal Kitabevi.

Sart, Z. H. (2007). Engelli çocukların eğitim hakkı: insan hakları çerçevesinde kaynaştırma/bütünleşme yoluyla eğitim. İçinde K. Çayır, M. Soran, M. Ergün (Der.). Engellilik ve ayrmolllk: Eğitimciler için temel metinler ve örnek dersler. İstanbul: Karekök Akademi, 2015. Erişim: http://secbir.org/images/2019/pdf/metin7.pdf

Sülün, K. ve Girli, A. (2016). İlköğretim genel eğitim sınıfı ile özel eğitim sınıfında öğrenim gören kaynaştırma öğrencilerinin sosyal becerilerinin incelenmesi. Batı Anadolu Eğitim Bilimleri Dergisi, 7(13), 1-24.

Ulutaşdemir, N. (2007). Engelli çocukların eğitimi. Furat Sağlık Hiæmetleri Dergisi, 2(5), 119-130.

Usta, M. (2009). Özel eğitim gerektiren, birey, aile ve din eğitimi. Din Eğitimi Araştırmalar Dergisi, 20, 75-110

Yıldırım, A. ve Şimşek H. (2016). Sosyal bilimlerde nitel araștırma yöntemleri. Ankara: Seçkin Yayıncllık.

Yıldırım-Doğru, S., Özlü, Ö., Kançeşme, C. ve Doğru, S. (2015). Özel eğitim üzerine yapılan proje çalışmalarının değerlendirilmesi. Abant İzzet Baysal Üniversitesi Eğitim Fakültesi Dergisi, 15(Özel Sayı), 286-296

Türkiye İstatistik Kurumu [TÜİK] [Turkish Statistical Institute] (2002). Türkiye özürlüler araştırmas1 [TÖA]. (2002). https://kutuphane.tuik.gov.tr/pdf/0014899.pdf

World Health Organization [WHO] (2011). World report on disability. Retrieved from https://www.who.int/disabilities/world_report/2011/en/

http://www.hurriyet.com.tr/ozel-egitim-ve-rehabilitasyon-merkezi-sayisi-2-bin-178-0603781/erş.tar.:08.03.2019.

https://orgm.meb.gov.tr/erş.tar.26.05.2019

http://www.resmigazete.gov.tr/eskiler/2007/02/20070214-1.htm.erş. tar.:28.02.2019. 


\section{EXTENDED ABSTRACT}

Disability is a concept that emphasizes the individual's physical, mental and mental functions in some movements or sensory organs for any reason. The reasons for the occurrence of disability are explained for three different reasons. The first one is the causes of prenatal. For example, maternal age, nutrition, drugs used, radiation exposure are suggested to cause disability. Second, the birth order is the reasons. For example, early-late birth, cord entanglement, birth order accidents, such as causes. The third reason is the postpartum causes. Exposure to infection after birth, negative effects of diseases, wrong and late intervention in the disease process are reasons such as. Therefore, $15 \%$ of the world's population is composed of disabled individuals. The population of people with disabilities in Turkey Disability Survey conducted in 2002 is $12.29 \%$ according to the results. Education is the process of changing behavior in the general sense. In a broad sense, it refers to all social processes that are effective in gaining individual's social standards, beliefs and ways of living. It is important to provide the necessary social, economic and physical conditions, treatment, care and rehabilitation opportunities for individuals with disabilities such as education and employment and socialization. This research focuses on the views of the disabled people on special education in Special Education and Rehabilitation Centers. The aim of the research is to reveal the educational status of Special Education and Rehabilitation Centers.

For this purpose, answers to these research questions were sought.

1. What frequent is the attendance of the disabled people to the Special Education and Rehabilitation Centers?

2. How do disabled individuals evaluate the education they receive at the Special Education and Rehabilitation Centers?

3. What are the views of the disabled individuals on Special Education and Rehabilitation Centers?

Among the qualitative research methods, the case study pattern was chosen as a model. Therefore, this research has been selected as an action research pattern was selected for this research because it focuses on the educational conditions of people with disabilities, and focuses on the change, especially the change in their personal lives through the education of these individuals. The research was carried out in 12 out of 18 Special Education and Rehabilitation Centers in the central districts of Van. The study group consisted of 18 people with disabilities. Of these individuals, 8 had vision and 6 had orthopedic disabilities, 2 had Multiple Sclerosis (MS) and 2 had Cerebral Palsy (SP). Members of the study group was intentionally selected from different types of disabilities. Therefore, the study group was determined based on purposive sampling. In other words, the selection of the study group from different types of disability and high self-expressing individuals was assumed to provide research data from a more qualified and reliable source. The study started in October 2018 and was completed in January 2019. The related literature review was conducted and interview questions were prepared. Research data were collected through demographic information form and semi-structured interview form. The data were obtained through recording Interviews with a voice record device during the research. In addition, observations were made in Special Education and Rehabilitation Centers and information was obtained about disabled individuals. Voice records were decoded into scripts. Research data is presented in more than one subcategory depending on four categories. Internal consistency between the data is provided according to expert opinions. Thus, the data are presented with descriptive analysis in accordance with certain categories.

More than $55.5 \%$ of the participants in the study found that they continued education and rehabilitation centers for more than two years and that they were trained in more than one different Special Education and Rehabilitation Center. It was determined that the participants were able to go to the Special Education and Rehabilitation Centers twice a week for two hours a week, both group and individual training, according to the types of disabilities and to the individual needs. As a result of the trainings they received at the Special Education and Rehabilitation Centers, it has been revealed that the visually impaired individuals can pass to reading with braille alphabets, and the psycho-motor skills of the physically disabled individuals have gained a functional dimension. She found that going to the Special Education and Rehabilitation Centers created a social life and friendship environment, enabled them to leave the house, had a positive impact on their daily lives, and developed independent life skills. It was found that participants were satisfied with their education in general and that they accepted obstacle conditions by means of Special Education and Rehabilitation Centers, their social circles expanded, they were freed from loneliness and therefore life bonds were strengthened by these institutions and they were 
happy. Therefore, Special Education and Rehabilitation Centers serve as a lifeline for people with disabilities who want to get rid of the spiral of loneliness and exclusion in social life. Individuals with disabilities have the opportunity to re-engage in social life through such institutions. Disabled individuals realize the fact that disability is a social phenomenon. At the same time, it is thought that these institutions are for disabled people, forgetting the pains in their past lives, making their present lives meaningful and seeing as a means of connecting to the future with hope. Because the results of this study reveal significant differences compared to the results of other previous studies related to people with disabilities. Because there is no research on this subject in the literature. Therefore, this research is different from other research conducted for disabled people in the formal education institutions in the formal education institutions do not take the opportunity of disabled individuals through Private Special Education and Rehabilitation Centers, but 2 hours a week with the projection of keeping life projections. Likewise, this research has been an important research since it indicates the educational status of the disabled individuals in Special Education and Rehabilitation Centers. Based on the findings and results obtained from the research results, some suggestions were made for the future researches. 